\title{
Molecular analysis of Taro and Bali cattle using cytochrome oxidase subunit I (COI) in Indonesia
}

\author{
NI NYOMAN WERDI SUSARI ${ }^{1, \boldsymbol{}}$, PUTU SUASTIKA ${ }^{1}$, KADEK KARANG AGUSTINA $^{2}$ \\ ${ }^{1}$ Department of Basic Sciences, Faculty of Veterinary Medicine, Universitas Udayana. J1. PB. Sudirman, Denpasar 80238, Bali, Indonesia. \\ Tel.: +62-361-223791, `email: nnwsusari@unud.ac.id \\ ${ }^{2}$ Department of Public Health, Faculty of Veterinary Medicine, Universitas Udayana. Jl. PB. Sudirman, Denpasar 80238, Bali, Indonesia
}

Manuscript received: 14 October 2020. Revision accepted: 17 December 2020.

\begin{abstract}
Susari NNW, Suastika P, Agustina KK. 2021. Molecular analysis of Taro and Bali cattle using cytochrome oxidase subunit I (COI) in Indonesia. Biodiversitas 22: 165-172. Cytochrome oxidase subunit I (COI) is one of the molecular markers often used as a differentiator with many advantages in phylogeny analysis, and it thus rarely undergoes substitution. This research was conducted to characterize the genetics of Taro and Bali (Bos javanicus) cattle. Blood from the animals was collected from the jugularis vein and amplified by PCR. The target area was COI with a primer that was successfully amplified, namely the forward BICOIF (5'-TTCTCAACCAACCATAAAGATATTGG-3') and the reverse BICOIR fragment (5'-TAG-ACTTCGGGGTGTCCAAAGAATCA-3'). The PCR products' sequencing was carried out by phylogeny analysis using MEGA 6 software. The amplicon value that succeeded in electrophoresis was 710bp, while six polymorphic sites were obtained at base positions of 1, 300, 379, 675, 676, and 679. The haplotypes (Hap) obtained were 4, with a genetic distance that ranged from 0.000-0.001. The nitrogenous bases of the amino acid composition from the samples showed no significant difference. The phylogenetic tree (Tamura-Nei) classified the cattle into two clades with a genetic distance of 0.0005 .
\end{abstract}

Keywords: Bali cattle, cytochrome oxidase subunit I, MEGA 6, PCR, phylogenetic, Taro cattle

\section{INTRODUCTION}

The Bali cattle strain is one of the Indonesian banteng descendants (Bos javanicus) that has undergone domestication in the islands of Java, Bali, and Lombok (Besung et al. 2019; Dharmawan et al. 2020). In 2017, the Bali cattle population in Bali reached 507,000 heads. Their physical characteristics are easy to recognize, such as a deep breast with slender legs, brick red skin, mirror nose, black nails, and tail feathers (Suwiti et al. 2017). The feet under the carpal and tarsal joints, the skin of the backside, and the inner thighs are white. On the backside are black feathers forming an eel line, extending from the hump to the base of the tail (Mohamad et al. 2009). Bali cattle are well adapted to the subtropical climate in Southeast Asia and are perfect livestock for the local conditions in places like Bali, Java, Sumatra, and Sulawesi (Mohamad et al. 2012).

Currently, there are three local cattle breeds characterized by their phenotypes in Indonesia, while many are yet uncharacterized and some are almost extinct or near extinction (Heryani et al. 2019). Therefore, the cattle's potential for genetic diversity can be used as a source of improving their quality (Wulandari et al. 2019). Some cattle types that have been characterized as phenotypic include Bali and Madura cattle (Lelana et al. 2003).

In addition to Bali cattle, there are also some groups with a very small population in the forests of Taro Village, Tegallalang Sub-district, Gianyar District, Bali Province: these are the white Taro cattle (Heryani et al. 2019). In general, there is a significant difference between the bodies of Bali and Taro cattle, something which is most clearly seen in the Taro cattle's white skin color. Due to the comparatively small population number, there is limited information available on their breeding patterns, and inbreeding still occurs. The exact origin of the Taro cow is unknown. However, Bali cattle are known to produce albino offspring (Sudrana et al. 2014). There are 51 Taro cattle found in the Taro forest region of Tegalalang, Gianyar, Bali, Indonesia.

Mitochondrial DNA is one of the cell organelles, the largest in structure in the cytoplasm. It is composed of two membranes, the outer and inner, each containing a lipoprotein molecule layer and consisting of a DNA genome (Schenkel and Bakovic 2014). The cytochrome oxidase subunit I gene is a coding protein in mitochondrial DNA and has been widely used as an identification tool for animal species (Pentinsaari et al. 2016). The 5 ends of COI, which has a length of 650 bases, is an area widely used as a DNA barcode (Hebert et al. 2003). COI effectiveness has been tested on various fauna and distinguished using DNA barcodes. This effectiveness is caused by low intraspecific variations, especially in adjacent taxa (Hajibabaei et al. 2006). It has been established that the COI techniques in other animals, such as metazoan invertebrates (Folmer et al. 1994), Tegal ducks (Anas domesticus) (Wibowo et al. 2013), Holothuroidea (Sahriyani et al. 2014), slow loris (Nycticebus spp) (Wirdateti et al. 2016), and Lepidoptera noctuidae (Suriana et al. 2019). 
Research on molecular characterization in Bali cattle according to the COI marker gene has not been performed; therefore, data on the genetic characteristics are still limited. This study aims to determine the molecular characterization of Taro and Bali cattle in Bali using COI markers. The data from their genetic structure are used as a basis for breeding strategies and for the purpose of conserving Taro cattle in Bali.

\section{MATERIALS AND METHODS}

\section{Ethical statement}

This research was approved by the Animal Ethics Committees of the Faculty of Veterinary Medicine Udayana University, Bali, Indonesia with Ref. No. 3172A/UN14.2.9/PD/2019.

\section{Research samples}

The materials used were 10 Taro and 20 Bali cattle (Figure 1). The Taro cattle were obtained from Taro Village, Tegalalang Sub-district, and Gianyar District. Bali cattle were obtained from (i) Ped Village, Nusa Penida, Klungkung District, (ii) Sobangan Village, Mengwi, Badung District, and (iii) Mekarsari Village, Bebalang, Bangli District. The blood samples from both cattle were taken as much as $5 \mathrm{~mL}$ using a venoject on the jugular vein and accommodated into a test tube containing Ethylene Diamine Tetraacetic Acid (EDTA) as an anticoagulant.

\section{DNA extraction}

The mitochondrial DNA was extracted from the total red blood using DNeasy® blood kits (Qiagen, USA). Then, $100 \mu \mathrm{L}$ red blood sample was inserted into a $2 \mathrm{~mL}$ microcentrifuge tube with $20 \mu \mathrm{L}$ proteinase $\mathrm{K}$ added. Phosphate-buffered saline (PBS) was also added to a volume of $220 \mu \mathrm{L}$, after which 2001 of Buffer $\mathrm{AL}$ was added, homogenized using a vortex, and incubated at $56^{\circ} \mathrm{C}$ for $10 \mathrm{~min}$. Then, $200 \mu \mathrm{L}$ ethanol was added (96-100\%) to the sample and homogenized again using a vortex. The mixture from the third process was taken with a pipette and
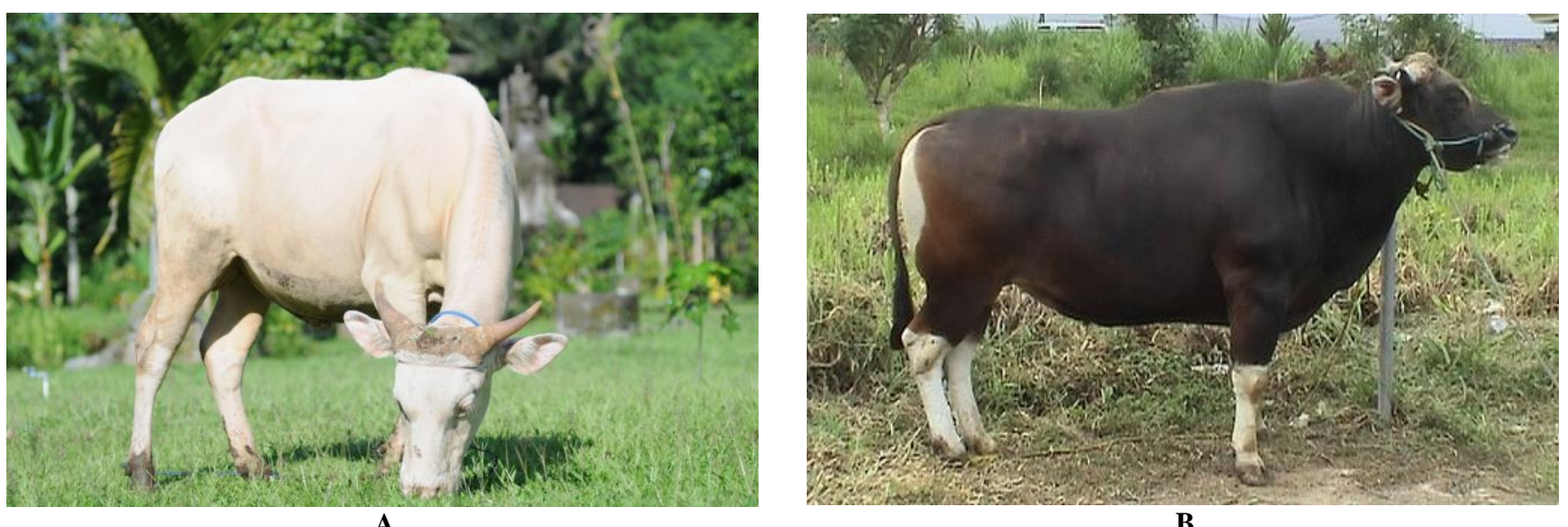

inserted into a $2 \mathrm{~mL}$ DNeasy Mini spin column, centrifuged at a speed of 8,000 rpm for $1 \mathrm{~min}$. The DNeasy Mini spin column was inserted into a $2 \mathrm{~mL}$ tube; $500 \mu \mathrm{L}$ Buffer AW1 was then added and centrifuged for $1 \mathrm{~min}$ at a speed of $8,000 \mathrm{rpm}$. The DNeasy Mini spin column from the above centrifuge results was inserted back into a new $2 \mathrm{~mL}$ tube along with $500 \mu \mathrm{L}$ of Buffer AW2 and then centrifuged for $3 \mathrm{~min}$ at a speed of 14,000 rpm. The DNeasy Mini spin column was reinserted into another new $2 \mathrm{~mL}$ centrifuge tube, joined with $200 \mu \mathrm{L}$ AE buffer, incubated at room temperature for $1 \mathrm{~min}$, and then centrifuged at 8,000 rpm. The obtained DNA was then stored at $2-8^{\circ} \mathrm{C}$ until the next use. The presence or absence of extracted DNA was then checked with gel electrophoresis by staining with ethidium bromide and observing with ultraviolet (UV) light. The DNA extraction results were then used for the PCR.

\section{Polymerase chain reaction (PCR)}

The PCR reaction was carried out using a Thermocycler Eppendorf machine in pre-denaturation at $95^{\circ} \mathrm{C}$ for $5 \mathrm{~min}$. The PCR cycle was performed 35 times under denaturation at $95^{\circ} \mathrm{C}$ for $45 \mathrm{sec}$ with primer attachment at $58^{\circ} \mathrm{C}$ for 1 min. The extension was started at $72^{\circ} \mathrm{C}$ for $1 \mathrm{~min}$ and terminated by post-extension at $72^{\circ} \mathrm{C}$ for $5 \mathrm{~min}$. The resulting PCR product was $710 \mathrm{bp}$, and a 2400 GeneAmpRPCR system was used for DNA amplification (Perkin Elmer). This reaction was performed to amplify the mitochondrial DNA in cytochrome oxidase subunit I with the forward BICOIF (5'-TTCTCAACCAACCATAAA GATATTGG-3) and the reverse BICOIR (5'TAGACTTCGGGTGTCCAAAA) (Wulandari et al. 2019). The PCR products were detected by electrophoresis on $1.2 \%$ agarose gel using a $1 \times$ TBE buffer. The observation was carried out using UV light $(=300 \mathrm{~nm})$ after staining the gel with ethidium bromide. The COI marker that was successfully amplified was used as a molecular weight indicator, with a size of $100 \mathrm{bp}$. PCR product sequencing was carried out at the Berkeley Sequencing Facility, University of California, Berkeley, USA, to obtain the nucleotide series.

Figure 1. A. Male Taro cattle, B. Male Bali cattle 


\section{Statistical analysis}

The sequence results were analyzed using MEGA 6 software. The phylogenetic tree uses the neighbor joining method with two Kimura's parameters and maximum likelihood reconstructed (Tamura et al. 2013).

\section{RESULTS AND DISCUSSION}

\section{Results}

COI from 10 Taro and 20 Bali cattle was successfully extracted and amplified by PCR using forward BICOIF (5'TTC-TCAACCAACCATAAAGATATTGG-3') and reverse BICOIR primers (5'-TAG-ACTTCGGTA-3'), with an amplitude of 710 bp (ML 3) (Figure 2).

The sequencing of all cattle genes from Taro and Bali cattle from Sobangan, Bangli, and Nusa Penida analyzed using MEGA 6 software obtained six polymorphic sites, which were in the $1,300,379,675,676$, and 679 base positions (Table 1).

Table 1. Polymorphic sites from COI sequencing of Taro cattle (W1-W8) and Bali cattle (Sobangan_SB; Bangli_B; Nusa Penida_NP)

\begin{tabular}{|c|c|c|c|c|c|c|}
\hline \multirow[t]{2}{*}{ Sample } & \multicolumn{6}{|c|}{ Base Position } \\
\hline & 1 & 300 & 379 & 675 & 676 & 6799 \\
\hline W1 & A & $\mathrm{T}$ & A & $\mathrm{C}$ & $\mathrm{T}$ & $\mathrm{G}$ \\
\hline W2 & . & . & . & . & . & . \\
\hline W3 & . & . & . & . & . & . \\
\hline W4 & . & . & . & . & . & . \\
\hline W5 & . & . & . & . & . & . \\
\hline W6 & $\mathrm{T}$ & . & . & . & . & . \\
\hline W7 & . & . & . & . & . & . \\
\hline W8 & . & . & . & . & . & . \\
\hline SB1 & . & . & . & . & . & . \\
\hline SB2 & . & . & . & . & . & . \\
\hline SB3 & . & . & . & . & . & . \\
\hline SB4 & . & . & . & . & . & . \\
\hline SB5 & . & . & . & . & . & . \\
\hline B1 & . & . & . & . & . & . \\
\hline B2 & . & . & . & . & . & . \\
\hline B3 & . & . & . & . & . & . \\
\hline B4 & . & . & . & . & . & . \\
\hline B5 & . & . & . & . & . & . \\
\hline NP12 & . & . & . & . & . & . \\
\hline NP13 & . & . & . & . & . & . \\
\hline NP14 & . & . & . & . & . & . \\
\hline NP15 & . & . & . & . & . & . \\
\hline NP16 & . & A & G & . & . & . \\
\hline NP17 & . & . & . & . & . & . \\
\hline NP18 & . & . & . & . & . & . \\
\hline NP19 & . & . & . & . & . & . \\
\hline NP20 & . & . & . & A & $\mathrm{C}$ & $\mathrm{T}$ \\
\hline NP21 &. & . & . & . & . & . \\
\hline
\end{tabular}

There were four haplotypes, and those for Taro cattle were shown in hap_2 owned by sample Taro number 6 (W6/Taro sample number 6), while the hap_3 and hap_4 were owned by Bali samples of number 16 (Nusa Penida number 16) and 20 (Nusa Penida number 20), respectively, which were the origin of Nusa Penida (Table 2).

The base content of thymine in Taro cattle ranges from $28.8-29.1 \%, 26.0-27.0 \%$ cytosine, $27.9 \%$ adenine, and $16.2-16.3 \%$ guanine, while the base content of thymine in Bali cattle ranges from 28.8-29.1\%, 26.7-27.0\% cytosine, $27.9-28.0 \%$ adenine, and $16.2-16.4 \%$ guanine (Table 3). There were nitrogen base substitutions (base-N), namely AT, T-A, A-G, C-A, T-C, and G-T, as shown in Table 1.

Table 2. The number of haplotypes in each location

\begin{tabular}{lllll}
\hline Sample & Taro & Sobangan & Bangli & $\begin{array}{c}\text { Nusa } \\
\text { Penida }\end{array}$ \\
\hline Hap1 & 7 & 5 & 5 & 8 \\
Hap2 & 1 & 0 & 0 & 0 \\
Hap3 & 0 & 0 & 0 & 1 \\
Hap4 & 0 & 0 & 0 & 1 \\
Total & 8 & 5 & 5 & 10 \\
\hline
\end{tabular}

Note: Hap: Haplotype

Table 3. The nitrogen composition of Taro and Bali cattle

\begin{tabular}{ccccc}
\hline Sample & T(U) & C & A & G \\
\hline W1 & 28.8 & 27.0 & 27.9 & 16.2 \\
W2 & 28.8 & 27.0 & 27.9 & 16.2 \\
W3 & 28.8 & 27.0 & 27.9 & 16.2 \\
W4 & 28.8 & 27.0 & 27.9 & 16.2 \\
W5 & 28.8 & 27.0 & 27.9 & 16.2 \\
W6 & 29.1 & 26.7 & 27.9 & 16.3 \\
W7 & 28.8 & 27.0 & 27.9 & 16.2 \\
W8 & 28.8 & 27.0 & 27.9 & 16.2 \\
Mean & $\mathbf{2 8 . 8}$ & 27 & $\mathbf{2 7 . 9}$ & 16.2 \\
SB1 & 28.8 & 27.0 & 27.9 & 16.2 \\
SB2 & 28.8 & 27.0 & 27.9 & 16.2 \\
SB3 & 28.8 & 27.0 & 27.9 & 16.2 \\
SB4 & 29.0 & 26.8 & 27.9 & 16.3 \\
SB5 & 28.8 & 27.0 & 27.9 & 16.2 \\
B1 & 28.8 & 26.9 & 28.0 & 16.3 \\
B2 & 28.8 & 27.0 & 27.9 & 16.2 \\
B3 & 28.8 & 27.0 & 27.9 & 16.2 \\
B4 & 28.8 & 27.0 & 27.9 & 16.2 \\
B5 & 28.8 & 27.0 & 27.9 & 16.2 \\
NP12 & 28.8 & 27.0 & 27.9 & 16.2 \\
NP13 & 28.8 & 27.0 & 27.9 & 16.2 \\
NP14 & 28.8 & 27.0 & 27.9 & 16.2 \\
NP15 & 28.8 & 27.0 & 27.9 & 16.2 \\
NP16 & 28.7 & 27.0 & 27.9 & 16.4 \\
NP17 & 28.8 & 27.0 & 27.9 & 16.2 \\
NP18 & 28.8 & 27.0 & 27.9 & 16.2 \\
NP19 & 28.8 & 27.0 & 27.9 & 16.2 \\
NP20 & 29.1 & 26.7 & 28.0 & 16.2 \\
NP21 & 28.8 & 27.0 & 27.9 & 16.2 \\
Mean & $\mathbf{2 8 . 8}$ & 27 & $\mathbf{2 7 . 9}$ & 16.2 \\
\hline & & & &
\end{tabular}


Table 4. Genetic distance of Taro and Bali cattle

\begin{tabular}{lcccc}
\hline & Taro & Sobangan & Bangli & Nusa Penida \\
\hline Taro & -- & -- & -- & -- \\
Sobangan & 0.000 & -- & -- & -- \\
Bangli & 0.000 & 0.000 & -- & -- \\
Nusa Penida & 0.001 & 0.001 & 0.001 & -- \\
\hline
\end{tabular}

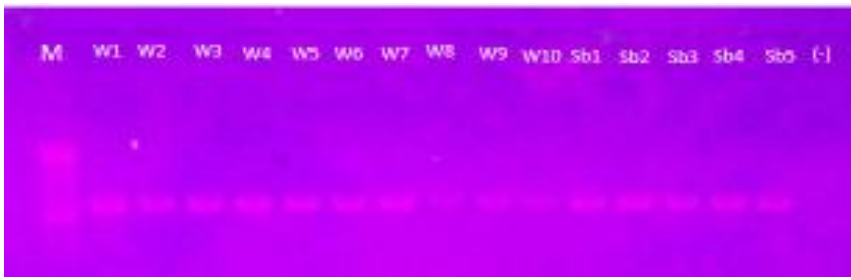

The values of genetic distances between Taro and Bali cattle from Sobangan, Bangli, and Nusa Penida ranged from 0-0.001. Detailed information about genetic distance values is presented in Table 4 .

Figure 2. (A and B) Electrophoresis of PCR amplicon (Taro cattle; W1-W10, Sobangan Bali cattle; Sb1-Sb5, Bangli Bali cattle; B1-B5, Nusa Penida Bali cattle; NP12-NP21) with 1\% agarose gel and ethidium bromide staining using 100bp DNA ladder marker (M) and (-) negative control.
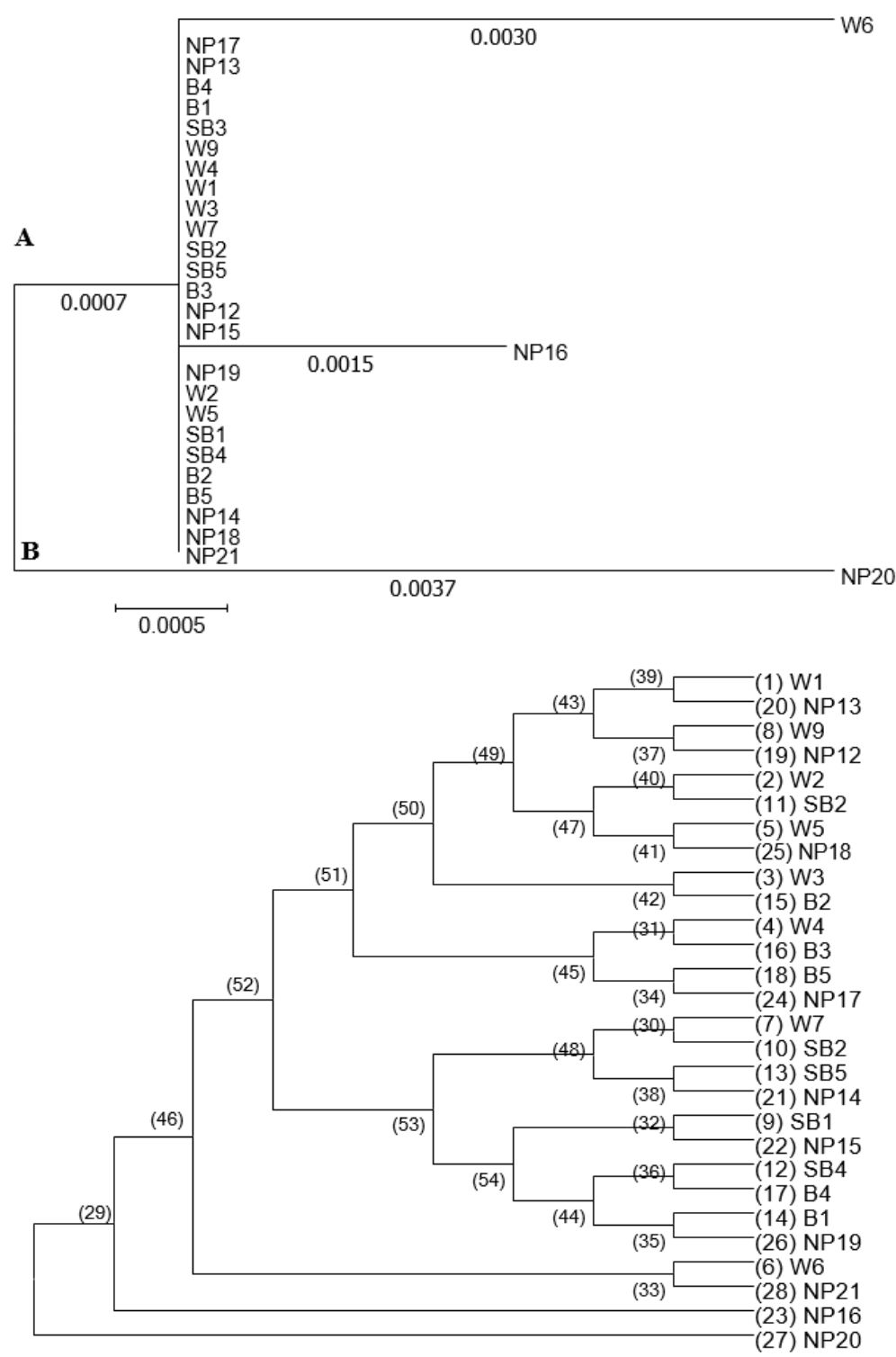

Figure 3. Phylogenetic tree using the neighbor-joining method with two Kimura's parameters and maximum likelihood reconstructed by MEGA 6 from 8 Taro cattle and 20 Bali cattle of the COI. The phylogenetic relationship was supported by the low genetic distance analysis, which showed no significant difference from nucleotide bases between the cattle. 


\section{Discussion}

The amplification results of Taro and Bali cattle using COI showed that the resulting bands in Bali cattle were thicker than those in the Taro. This was observed in three Taro samples, specifically 8, 9, and 10 bands (Figure 2). For Bali cattle, the primer attachment occurred specifically, since it uses the sequence of COI from Bos indicus. The amplification was also influenced by several factors, such as the type of primer used, DNA purification, and the PCR condition. According to prior publications, there were several obstacles that often occur in amplifying printed DNA, which produce multistrand bands that are not the targets (Hao et al. 2020). Cytochrome oxidase subunit I was selected as one of the genes whose sequences were used in barcoding and for determining species identity in higher animals (Hebert et al. 2003; Chao et al. 2014). This gene was also used to reconstruct phylogenetics at the species level of evolution (Gabaldón 2005; Cai and Ma 2016).

Haplotypes reveal the genetic variation within a species based on the nucleotide sequence (Garg and Mishra 2018; Phillips et al. 2019). There were four haplotypes (Hap) from both cattle (Table 2), namely haplotype_1 (Hap_1) found in Taro samples 1, 2, 3, 4, 5, 7, and 9, while in Bali cattle from Sobangan, it was found in numbers 1, 2, 3, 4, and 5. Also, in the Bali cattle sample from Bangli, it was found in numbers 1, 2, 3, 4, and 5, while in Bali cattle from Nusa Penida, it was found in numbers 12, 13, 14, 15, 17, 18,19 , and 21. Haplotype_2 (Hap_2) was found in Taro sample number 6. Haplotype_3 (Hap_3) was found in Bali cattle from Nusa Penida, sample 16. Haplotype_4 (Hap_4) was found in Bali cattle from Nusa Penida, sample 20. Haplotype_1 was found in almost all samples, an indication of inbreeding in the population. The relationship between Taro and Bali cattle showed that inbreeding had been in existence in the village forest decades ago. Therefore, the greater the variety of haplotype composition in one population, the greater the genetic diversity (Thomas et al. 2012; Akbar et al. 2014; Yang et al. 2019; Yun et al. 2020).

Furthermore, the typical haplotype of Taro cattle shown in Hap_2 belongs to sample 6, with a difference in one nucleotide base. Meanwhile, the typical haplotypes of Bali cattle from Nusa Penida were shown by Hap_3 and Hap_4 in samples 16 and 20. The mutations that occurred in the mitochondrial DNA genome sequence produced a unique gene arrangement, which was observed from the grouping in the phylogeny tree (Gissi et al. 2008; Tyagi et al. 2020).

The base content of thymine in Taro cattle was 28.8 $29.1 \%$, cytosine $26.0-27.0 \%$, adenine $27.9 \%$, and guanine $16.2-16.3 \%$. The base content of thymine in Bali cattle was 28.8-29.1\%, cytosine 26.7-27.0\%, adenine 27.9-28.0\%, and guanine $16.2-16 \%$ (Table 3 ). Therefore, adenine and thymine (AT) contents were relatively higher than those of cytosine and guanine (CG). These were in accordance with the results of several studies in other species, which showed that mitochondrial genes, especially those of COI, were rich in adenine and thymine (da Silva et al. 2011; Gonçalves et al. 2015; Hashemi-Aghdam et al. 2017; Morlais and Severson 2002; Suriana and Nasaruddin 2017). The composition of the $\mathrm{N}$ base was also related to that of amino acids encoded by the gene; therefore, a change in the composition of the nucleotide caused an alteration in the genetic code (Mitra et al. 2016). However, these changes do not always lead to alterations in the genes, since there were amino acids coded for more than one genetic sequence. The cytochrome-C oxidase genes were coded for functional cytochrome amino acids (Pierron et al. 2014; Skibinski et al. 2017; Sabir et al. 2019). The amino acid composition of the protein encoded in the COI gene rarely undergoes substitution (Quax et al. 2015; Liu et al. 2017). Therefore, the COI gene was stable and used as a marker for phylogeny analysis; however, the bases in the triple codon were still changing (Buhay 2009; Muyle et al. 2011; Wahlberg and Wheat 2008).

The polymorphic sites indicated the differences between individuals within one species (Jaratlerdsiri et al. 2014; Viscardi et al. 2018; Brodetzki et al. 2019; Takahashi-Kariyazono et al. 2020). The research on several mitochondrial genes also showed some intra-population variation, and their differences were used as genetic markers (barcode species) (Li et al. 2008; Meenakshi et al. 2010; Yaacov et al. 2012; Wolff et al. 2014; Naim et al. 2020). The difference in the composition and nitrogen base sequence (base $\mathrm{N}$ ) in genes was caused by point mutations, such as the substitution of an N-base for another (Griffiths et al. 1999; Clutterbuck 2011).

The phylogenetic relationship between both cattle was supported by genetic analysis with a distance of $0-0.001$ (Figure 3). The low genetic distance indicated no significant difference in the nucleotide bases between the cattle, which showed that the nucleotides were still maintained between individuals in one species. This was in accordance with the research stating that the smaller the value of genetic distance, the closer the kinship (Kim et al. 2002). Similar research has also been carried out on several local cattle in Indonesia showing no genetic distance between Pasundan cattle, Madura cattle, and Bali cattle (Wulandari et al. 2019). This result is contradicted by Shaari et al. (2019), when the Murrah buffalo in that study were placed in the different sub-clades even though they were sampled from the same farm (Shaari et al. 2019). The genetic distance among the Taro cattle using molecular markers D-Loop mtDNA and cytochrome B also showed low values at 0.002 and 0.017 (Susari and Heryani 2018). Therefore, the genetic distance value was directly proportional to the number of nucleotide bases and vice versa (Kaehler et al. 2015; Kosman and Jokela 2019). The relationship between several local cattle was probably due to the gene flow that occurred in their geographic location (Abdullah et al. 2012; Senczuk et al. 2020). Cross-breeding between species is possible if closely related species are in the same habitat or if there was human intervention during rearing (Nijman et al. 2003).

The phylogenetic tree showed that Bali cattle sample 16 (NP16) and Taro sample 6 (W6) had haplotype arrangements in the same cluster manner (A), while Bali cattle from Nusa Penida, sample 20 (NP20), were in a different cluster (B) with varied haplotype arrangements. The difference in the haplotype arrangement was found at one polymorphic site, as a thymine $(\mathrm{T})$ base; therefore, the 
samples of Bali from Nusa Penida (NP20) and Taro cattle (W6) had specific characteristics and genetic markers. The different lengths of the branches indicate that the sequence has a change of nucleotide (Hall 2001). The cytochrome-C oxidase gene has polymorphisms in several parts; therefore, each species varies in terms of base-N composition (Zhao et al. 2013; Rodrigues et al. 2017). This variation also gives species distinctive features as genetic markers ( $\mathrm{Li}$ et al. 2015; Pentinsaari et al. 2016).

It can thus be seen that the genetic diversity level of Taro and Bali cattle obtained was low, as indicated by the small number of haplotypes. The phylogenetic relationship had a genetic distance of 0-0.001, and the overall genetic characters correlated with Bali cattle. Based on the proximity of this genetic distance, it can be assumed that Taro and Bali cattle evolved from a common ancestor. Organisms or species that have many similarities in character are considered to have a close relationship and be descended from one common ancestor (Van Berkum et al., 1995).

\section{ACKNOWLEDGEMENTS}

The authors would like to thank the Chairperson of Research and Community Service of Udayana University through the DIPA PNBP in accordance with the Letter of Agreement Number: 0789/UN14.2.9/LT/2018, April 5, 2018. They would also like to thank the Biomedical Laboratory, Faculty of Veterinary Medicine, Udayana University, for its permission to use the laboratory for this research. Additionally, they extend their warmest gratitude to the Indonesian Biodiversity Research Center for helping to send the DNA samples to complete sequencing.

\section{REFERENCES}

Abdullah MAN, Noor RR, Martojo H, Solihin DD. 2012. Genetic characterization of the Aceh cattle using phenotypic, mitochondrial DNA of D-loop region and microsatellite DNA analyses. reproduction in domestic animals 47 (suppl. 1): 15-17. DOI: 10.1111/j.1439-0531.2011.01959.x.

Akbar N, Zamani NP, Madduppa H. 2014. Genetic diversity of yellowfin tuna (Thunnus albacares) from two populations in the Moluccas Sea Indonesia. Depik 3 (1): 65-73.

Bar Yaacov D, Arbel-Thau K, Zilka Y, Ovadia O, Bouskila A, Mishmar D. 2012. Mitochondrial DNA variation, but not nuclear DNA, sharply divides morphologically identical chameleons along an ancient geographic barrier. PLoS ONE 7 (3): e31372. DOI: 10.1371/journal.pone.0031372.

Besung INK, Watiniasih NL, Mahardika GNK, Agustina KK, Suwiti NK 2019. Mineral levels of bali cattle (Bos javanicus) from different types of land in bali, nusa penida, and sumbawa islands (Indonesia). Biodiversitas 20 (10): 2931-2936. DOI: 10.13057/biodiv/d201022.

Brodetzki TR, Inbar S, Cohen P, Aron S, Privman E, Hefetz A. 2019. The interplay between incipient species and social polymorphism in the desert ant cataglyphis. Sci Rep 9 (1): 9495. DOI: 10.1038/s41598019-45950-1.

Buhay JE. 2009. "Coi-like" sequences are becoming problematic in molecular systematic and DNA barcoding studies. J Crustacean Biol 29 (1): 96-110. DOI: 10.1651/08-3020.1.

Cai L, Ma H. 2016. Using nuclear genes to reconstruct angiosperm phylogeny at the species level: A case study with Brassicaceae species. J Syst Evol 54 (4) 438-452. DOI: 10.1111/jse.12204.
Chao Z. Liao J, Liang Z, Huang S, Zhang L, Li J. 2014. Cytochrome C oxidase subunit I barcodes provide an efficient tool for Jinqian Baihua She (Bungarus parvus) authentication, Pharmacogn Mag 10 (40): 449-457. DOI: 10.4103/0973-1296.141816.

Clutterbuck JA. 2011. Genomic evidence of repeat-induced point mutation (RIP) in filamentous ascomycetes. Fungal Genet Biol 48 (3): 306326. DOI: 10.1016/j.fgb.2010.09.002.

da Silva JM, dos Santos A, Costa AC, Cunha MR, Costa FO, Carvalho GR. 2011. Systematic and evolutionary insights derived from mtDNA COI Barcode diversity in the Decapoda (Crustacea: Malacostraca). PLoS ONE 6 (5): e0019449. DOI: 10.1371/journal.pone.0019449.

Dharmawan NS, Damriyasa IM, Mahardika IG, Swastika K, Hartiningsih LP, Agustina KK. 2020. A seroepidemiological study of bovine cysticercosis in Bali and Nusa Tenggara, Indonesia. Vet World 13 (2): 284-289. DOI: 10.14202/vetworld.2020.284-289.

Folmer O, Black M, Hoeh W, Lutz R, Vrijenhoek R. 1994. DNA primers for amplification of mitochondrial cytochrome c oxidase subunit I from diverse metazoan invertebrates. Mol Mar Biol Biotech 3 (5): 294-299. DOI: 10.1071/ZO9660275

Gabaldón T. 2005. Evolution of proteins and proteomes: a phylogenetic approach. Evol Bioinform Online 1 (1): 51-61. DOI: 10.1177/117693430500100004.

Garg RK, Mishra V. 2018. Molecular insights into the genetic and haplotype diversity among four populations of Catla catla from Madhya Pradesh revealed through mtDNA cyto b gene sequences. J Genet Eng Biotechnol 16 (1): 169-174. DOI: 10.1016/j.jgeb.2017.11.003.

Gissi C, Iannelli F. Pesole G. 2008. Evolution of the mitochondrial genome of Metazoa as exemplified by comparison of congeneric species. Heredity 101 (4): 301-320. DOI: 10.1038/hdy.2008.62.

Gonçalves R, Freitas AI, Jesus J, Rúa PDL, Brehm A. 2015. Structure and genetic variation of the mitochondrial control region in the honey bee Apis mellifera, Apidologie 46 (4): 515-526. DOI: 10.1007/s13592014-0341-y.

Griffiths AJF, Gelbart WM, Miller JH. 1999. Modern Genetic Analysis. WH Freeman \& Co., USA.

Hajibabaei M, Janzen DH, Burns JM, Hallwachs W, Hebert PDN. 2006. DNA barcodes distinguish species of tropical Lepidoptera. Proc Natl Acad Sci USA 103 (4): 968-971. DOI: 10.1073/pnas.0510466103.

Hall BG. 2001. Phylogenetic Trees Made Easy: A How-To Manual for Molecular Biologists. Sinauer Associates, Sunderland. DOI: 10.1043/0363-6445-28.2.465.

Hao M, Qiao J, Qi H. 2020. Current and emerging methods for the synthesis of single-stranded DNA. Genes 11 (2): 1-15. DOI: 10.3390/genes11020116.

Hashemi-Aghdam SS, Rafie G, Akbari S, Oshaghi MA. 2017. Utility of mtDNA-COI barcode region for phylogenetic relationship and diagnosis of five common pest cockroaches. J Arthropod-Borne Dis 11 (2): 172-183.

Hebert PDN, Cywinska A, Ball SL, deWaard JR. 2003. Biological identifications through DNA barcodes', Proc R Soc B 270 (1): 313321. DOI: 10.1098/rspb.2002.2218.

Heryani LGSS, Wandia IN, Suarna IW, Puja IK, Susari NNW, Agustina KK. 2019. Short communication: Molecular characteristic of taro white cattle based on DNA microsatellite markers. Biodiversitas 20 (3): 671-675. DOI: 10.13057/biodiv/d200308

Jaratlerdsiri W, Isberg SR, Higgins DP, Miles LG, Gongora J. 2014. Selection and trans-species polymorphism of major histocompatibility complex class II genes in the order Crocodylia. PLoS ONE 9 (2): 113. DOI: 10.1371 /journal.pone.0087534.

Kaehler BD, Yap VB, Zhang R, Huttley GA. 2015. Genetic distance for a general non-stationary Markov substitution process. Syst Biol 64 (2): 281-293. DOI: 10.1093/sysbio/syu 106.

Kim KI, Lee JH, Li K, Zhang YP, Lee SS, Gongora J, Moran C. 2002. Phylogenetic relationships of Asian and European pig breeds determined by mitochondrial DNA D-loop sequence polymorphism. Anim Genet 33 (1): 19-25. DOI: 10.1046/j.1365-2052.2002.00784.x.

Kosman E, Jokela J. 2019. Dissimilarity of individual microsatellite profiles under different mutation models: Empirical approach. Ecol Evol 9 (7): 4038-4054. DOI: 10.1002/ece3.5032.

Lelana NE, Sutarno, Etikawati N. 2003. Identification of polymorphism on ND-5 mitochondrial DNA fragment of Benggala and Madura cattle with PCR-RFLP technique. Biodiversitas 4 (1): 1-6. DOI: 10.13057/biodiv/d040101.

Li JT, Che J, Bain RH, Zhao E, Zhang Y. 2008. Molecular phylogeny of Rhacophoridae (Anura): A framework of taxonomic reassignment of 
species within the genera Aquixalus, Chiromantis, Rhacophorus, and Philautus. Mol Phylogenet Evol 48 (1): 302-312. DOI: 10.1016/j.ympev.2008.03.023.

Li X, Scanlon MJ, Yu J. 2015. Evolutionary patterns of DNA base composition and correlation to polymorphisms in DNA repair systems. Nucleic Acids Res 43 (7): 3614-3625. DOI: 10.1093/nar/gkv197.

Liu Y, Sharp JS, Do DH, Kahn RA, Schwalbe H, Buhr F, Prestegard JH. 2017. Mistakes in translation: Reflections on mechanism. PLoS ONE 12 (6): 1-13. DOI: 10.1371 /journal.pone.0180566.

Meenakshi K, Suraj T, Bhagwati SS, Sujith VG, Santhoshkumar K, Sanil G. 2010. Molecular resolution of four Fejervarya species from Western Ghats (India) with their intrageneric phylogeny based on COI, Cyt B, 12S and 16S rRNA Genes. Asian J Exp Biol Sci 1 (4): 782-786.

Mitra S, Ray SK. Banerjee R. 2016. Synonymous codons influencing gene expression in organisms. Res Rep Biochem 6 (1): 57-65. DOI: $10.2147 /$ rrbc.s83483.

Mohamad K, Olsson M, Andersson G, Purwantara B, van Tol HTA, Rodriguez-Martinez H, Colenbrander B, Lenstra JA. 2012. The origin of Indonesian cattle and conservation genetics of the Bali cattle breed. Reprod Domest Anim 47 (Suppl. 1): 18-20. DOI: 10.1111/j.14390531.2011.01960.x.

Mohamad K, Olsson M, van Tol HT, Mikko S, Vlamings BH, Andersson G, Rodríguez-Martínez H, Purwantara B, Paling RW, Colenbrander B, Lenstra JA. 2009. On the origin of Indonesian cattle. PLoS ONE 4 (5): 1-6. DOI: 10.1371/journal.pone.0005490.

Morlais, Severson DW. 2002. Complete mitochondrial DNA sequence and amino acid analysis of the cytochrome $\mathrm{C}$ oxidase subunit I (COI) from Aedes aegypti. DNA Sequence 13 (2): 123-127. DOI: $10.1080 / 10425170290030051$

Muyle A, Serres-Giardi L, Ressayre A, Escobar J, Glemin S. 2011. GCbiased gene conversion and selection affect GC content in the Oryza genus (rice). Mol Biol Evol 28 (9): 2695-2706. DOI: 10.1093/molbev/msr104.

Naim, DM, Kamal NZM, Mahboob S. 2020. Population structure and genetic diversity of Aedes aegypti and Aedes albopictus in Penang as revealed by mitochondrial DNA cytochrome oxidase I. Saudi J Biol Sci 27 (3): 953-967. DOI: 10.1016/j.sjbs.2020.01.021.

Nijman IJ, Otsen M, Verkaar ELC, de Ruijter C, Hanecamp E, Ochieng JW, Shamshad S, Rege JEO, Hanotte O, Barwegen MW, Sulawati T, Lenstra JA. 2003. Hybridization of banteng (Bos javanicus) and zebu (Bos indicus) revealed by mitochondrial DNA, satellite DNA, AFLP and microsatellites. Heredity 90 (1): 10-16. DOI 10.1038/sj.hdy.6800174

Pentinsaari M, Salmela H, Mutanen M, Roslin T. 2016. Molecular evolution of a widely-adopted taxonomic marker (COI) across the animal tree of life. Sci Rep 6 (1): 35275. DOI: 10.1038/srep35275.

Phillips JD, Gillis DJ, Hanner RH. 2019. Incomplete estimates of genetic diversity within species: Implications for DNA barcoding. Ecol Evol 9 (5): 2996-3010. DOI: $10.1002 /$ ece3.4757.

Pierron D, Wildman DE, Hüttemann M, Markondapatnaikuni GC, Aras S, Grossman LI. 2014. Cytochrome C oxidase: Evolution of control via nuclear subunit addition. Biochimica et Biophysica Acta 1817 (4): 590-597. DOI: 10.1016/j.bbabio.2011.07.007.Cytochrome.

Quax TEF, Claassens NJ, Söll D, van der Oost J. 2015. Codon bias as a means to fine-tune gene expression. Mol Cell 59 (2): 149-161. DOI: 10.1016/j.molcel.2015.05.035

Rodrigues MS, Morelli KA, Jensen AM. 2017. Cytochrome c oxidase subunit 1 gene as a DNA barcode for discriminating Trypanosoma cruzi DTUs and closely related species. Parasites Vectors 10 (1): 118. DOI: $10.1186 / \mathrm{s} 13071-017-2457-1$.

Sabir JSM, Rabah S, Yacoub H, Hajrah NH, Atef A, Al-Matary M, Edris S, Alharbi MG, Ganash M, Mahyoub J, Al-Hindi RR, Al-Ghamd KM, Hall N, Bahieldin A, Kamli MR, Rather IA. 2019. Molecular evolution of cytochrome $\mathrm{C}$ oxidase-I protein of insects living in Saudi Arabia. PLoS ONE 14 (11): e0224336. DOI: 10.1371/journal.pone.0224336.

Sahriyani N, Widodo, Toha AHA. 2014. Amplifikasi gen COI (Cytochrome C Oxidase Subunit I) pada holothuroidea yang dikoleks dari kepulauan Raja Ampat. Jurnal Biotropika 2 (4): 232-234. [Indonesian]

Schenkel LC, Bakovic M. 2014. Formation and regulation of mitochondrial membranes. Intl J Cell Biol 2014 (1): 709828. DOI: $10.1155 / 2014 / 709828$
Senczuk G, Mastrangelo S, Ciani E, Battaglini L, Cendron F, Ciampolini R, Crepaldi P, Mantovani R, Bongioni G, Pagnacco G, Portolano B, Rossoni A, Pilla F, Cassandro M. 2020. The genetic heritage of Alpine local cattle breeds using genomic SNP data. Genet Select Evol 52 (1): 40. DOI: 10.1186/s12711-020-00559-1.

Shaari NAL, Edward MJ, Loo SS, Salisi MS, Yusoff R, Ab Ghani NI, Saad MZ, Ahmad H. 2019. Karyotypic and mtDNA based characterization of Malaysian water buffalo. BMC Genet 20 (1): 1-6. DOI: 10.1186/s12863-019-0741-0.

Skibinski DOF, Ghiselli F, Diz AP, Milani L, Mullins JGL. 2017. Structure-related differences between cytochrome oxidase I proteins in a stable heteroplasmic mitochondrial system. Genome Biol Evol 9 (12): 3265-3281. DOI: 10.1093/gbe/evx235.

Sudrana IP, Lestari, Jan R, Rozy T, Kasip LM. 2014. The other colour pattern of Bali Cattle in West Lombok District. Jurnal Penelitian UNRAM 18 (1): 54-63. [Indonesian]

Suriana, Marwansyah, Amirullah. 2019. Karakteristik segmen gen sitokrom C Oksidase Subunit I (COI) Ngengat Plusia chalcites (Lepidoptera: Noctuidae). BioWallacea J Biological Research 6 (2): 985-994. DOI: 10.33772/biowallacea.v6i2.8824. [Indonesian]

Suriana, Nasaruddin. 2017. Characteristics of partial cytochrome c oxidase subunit I (COI) gene of tree frog (Polypedates celebensis) in Tanjung Peropa Wildlife Reserve Moramo, Southeast Sulawesi. $\begin{array}{lllll}\text { Jurnal } & \text { Veteriner } 17 & \text { (4): } & 517-523 . & \text { DOI: }\end{array}$ 10.19087/jveteriner.2016.17.4.517.

Susari NNW, Heryani LGSS. 2018. Genetic analysis of taro cattle (white, black, red) and Bali cattle using Cytochrome B. International Symposium in Veterinary Science, Udayana University, Denpasar, Bali, Indonesia

Suwiti NK, Besung INK, Mahardika GN. 2017. Factors influencing growth hormone levels of Bali cattle in Bali, Nusa Penida, and Sumbawa Islands, Indonesia. Vet World 10 (10): 1250-1254. DOI: 10.14202/vetworld.2017.1250-1254.

Takahashi-Kariyazono S, Sakai K, Terai Y. 2020. Presence-absence polymorphisms of single-copy genes in the stony coral Acropora digitifera. BMC Genom 21 (1): 158. DOI: 10.1186/s12864-020-65664 .

Tamura K, Stecher G, Peterson D, Filipski A, Kumar S. 2013. MEGA6: Molecular evolutionary genetics analysis version 6.0. Mol Biol Evol 30 (12): 2725-2729. DOI: 10.1093/molbev/mst197.

Thomas M, Demeulenaere E, Dawson JC, Khan AR, Galic N, JouannePin S, Remoue C, Bonneuil C, Goldringer I. 2012. On-farm dynamic management of genetic diversity: The impact of seed diffusions and seed saving practices on a population-variety of bread wheat. Evol Appl 5 (8): 779-795. DOI: 10.1111/j.1752-4571.2012.00257.x.

Tyagi, K, Chakraborty R, Cameron SL, Sweet AD, Chandra K, Kumar V. 2020. Rearrangement and evolution of mitochondrial genomes in Thysanoptera (Insecta). Sci Rep 10 (1): 1-16. DOI: 10.1038/s41598020-57705-4

Van Berkum P, Tully RE. Keister DL. 1995. Nonpigmented and bacteriochlorophyll-containing bradyrhizobia isolated from Aeschynomene indica. Appl Environ Microbiol 61 (2): 623-629. DOI: 10.1128/aem.61.2.623-629.1995.

Viscardi LH, Paixão-Côrtes VR, Comas D, Salzano FM, Rovaris D, Bau CD, Amorim CEG, Bortolini MC. 2018. Searching for ancient balanced polymorphisms shared between Neanderthals and modern humans. Genet Mol Biol 41 (1): 67-81. DOI: 10.1590/1678-4685gmb-2017-0308.

Wahlberg N, Wheat CW. 2008. Genomic outposts serve the phylogenomic pioneers: Designing novel nuclear markers for genomic DNA extractions of Lepidoptera. Syst Biol 57 (2): 231-242. DOI: 10.1080/10635150802033006

Wibowo SE, Djaelani MA, Kusumaningrum HP. 2013. Pelacakan gen sitokrom oksidase sub unit I (COI) DNA mitokondria itik Tegal (Anas domesticus) menggunakan primer universal. Bioma Berkala Ilmiah Biologi 15 (1): 20. DOI: 10.14710/bioma.15.1.20-26. [Indonesian]

Wirdateti, Indriana E, Handayani. 2016. Analisis sekuen DNA mitokondria cytochrome oxidase I (COI) mtDNA pada kukang Indonesia (Nycticebus spp.) sebagai penanda guna pengembangan identifikasi spesies. Jurnal Biologi Indonesia 12 (1): 119-128. [Indonesian]

Wolff JN, Ladoukakis ED, Enríquez JA, Dowling DK. 2014. Mitonuclear interactions: Evolutionary consequences over multiple biological scales. Phil Trans R Soc B 369 (1): 1-10. DOI: 10.1098/rstb.2013.0443. 
Wulandari A, Nurgiartiningsih VMA, Kuswati, Susilorini TE, Partogi PA. 2019. 'Kinship of several Indonesian local cattle by using DNA mitochondrial COI (Cytochrome Oxidase Sub-unit I). Intl Research J Advanced Engineering and Science 4 (3): 165-167.

Yang JY, Pak J-H, Maki M, Kim S-C. 2019. Multiple origins and the population genetic structure of Rubus takesimensis (Rosaceae) on Ulleung Island: Implications for the genetic consequences of anagenetic speciation. PLoS ONE 14 (9): 1-22. DOI: 10.1371/journal.pone.0222707.
Yun SA, Son HD, Im HT, Kim SC. 2020. Genetic diversity and population structure of the endangered orchid Pelatantheria scolopendrifolia (Orchidaceae) in Korea. PLoS ONE 15(8): 1-21. DOI: 10.1371 journal.pone.0237546.

Zhao Y, Gentekaki E, Yi Z, Lin X. 2013. Genetic differentiation of the mitochondrial cytochrome oxidase $\mathrm{C}$ subunit $\mathrm{I}$ gene in genus Paramecium (Protista, Ciliophora). PLoS ONE 8 (10): 1-8. DOI: 10.1371/journal.pone.0077044. 